\title{
A Pilot Study on the Impact of Pharmacist Intervention in Type-2 Diabetes Mellitus Counselling Program in a Rural Community
}

\author{
KRISHNAVENI KANDASAMY*, M. KONAKALLA, R. SAM, J. SEBASTIAN, A. NATARAJAN, S. S. RAJAGOPAL AND \\ S. RAMANATHAN \\ Department of Pharmacy Practice, J. K. K. Natarajah College of Pharmacy, Kumarapalayam, Namakkal-638 183, India
}

Krishnaveni, et al.: Impact of Pharmacist Intervention in Type-2 DM Patients

\begin{abstract}
Diabetes of all types can lead to complications and can increase the overall risk of dying prematurely, which include heart attack, stroke, kidney failure, leg amputation, vision loss and nerve damage. A randomized controlled pilot study was carried out for a period of 6 months to assess the impact of pharmacist intervention on blood glucose levels, quality of life, knowledge, attitude and practice in diabetic patients. The diabetic patients were randomized into control and intervention groups, using simple randomization techniques based on age; both the groups were interviewed using (1) knowledge, attitude and practices and (2) WHOQOLBREF questionnaires. Both the groups were screened for blood glucose levels at baseline and each followup. Only the intervention group was given counselling during the study period. The effect of pharmacist intervention on quality of life and knowledge, attitude and practices among control and intervention were statistically analysed by paired t-test using SPSS version 16. Out of the 60 patients, $24(40 \%)$ were males and $36(60 \%)$ were females. In our study, the quality of life score for each domain of both intervention and control groups was found to be non-significant at baseline and for the intervention group, a highly significant improvement $(\mathbf{P}<\mathbf{0 . 0 0 1})$ was observed for all domains in the final follow-up. Knowledge, attitude and practice score of intervention group also showed a significant improvement $(P<0.001)$ from baseline to final follow up. In this study, intervention group showed significant $(\mathrm{P}<0.001)$ mean reduction of blood glucose levels from baseline $166.1 \pm 66.60$ to final follow-up $118.27 \pm 11.70$. The results showed that significant reduction in blood glucose levels, enhancement in the quality of life and knowledge of patients in intervention group after pharmacist mediated counselling.
\end{abstract}

Key words: Diabetes mellitus type 2, patient counselling, fasting blood sugar, quality of life, knowledge, attitude, practice

Diabetes mellitus (DM) is one of the major health problems in the world. According to the Diabetes Atlas 2014,382 million people worldwide, or $8.3 \%$ of adults, were estimated to have DM. If these trends continue, by 2035 , some 592 million people, or one adult in 10 , will have diabetes. This may result in nearly three new cases every $10 \mathrm{~s}$ or almost 10 million/ $\mathrm{y}^{[1]}$. Almost half of all adults with DM are between the age group of 40 and $59 \mathrm{y}$. More than $80 \%$ of the 184 million people in the world live with DM in this age group in low- and middle-income countries. If this susceptible age group with DM continues to increase, it is expected that the numbers may increase to 264 million by $2035^{[1]}$. In India, the prevalence of DM is increasing, which may be attributed to changing lifestyle, sedentary occupation, and irregular food habits and therefore, prevention is the best strategy ${ }^{[2]}$.

*Address for correspondence E-mail: venidhiya@gmail.com

September-October 2017
Quality of life (QOL) is a main health outcome in DM patients ${ }^{[2]}$. Education and behaviour changes are required to manage the conditions and to improve QOL. Lifestyle changes must incorporate careful dietary planning, use of medication, and home blood sugar monitoring techniques for all DM patients ${ }^{[3]}$. Comorbidity with other diseases associated with DM may influence how a person with DM rate with their QOL. Poor management of DM leads to several complications and end organ damage that ultimately

This is an open access article distributed under the terms of the Creative Commons Attribution-NonCommercial-ShareAlike 3.0 License, which allows others to remix, tweak, and build upon the work non-commercially, as long as the author is credited and the new creations are licensed under the identical terms

Accepted 07 July 2017

Revised 02 February 2017

Received 11 August 2016

Indian J Pharm Sci 2017;79(5):701-706 
impairs the health related quality of life (HRQOL) in the individuals ${ }^{[4]}$.

In health care practice, therapeutic outcomes directly influences the physical, psychological and social domains of health, this will affects the overall $\mathrm{HRQOL}^{[5]}$. Adequate information on DM improves their psychological acceptance and control of disease. Thus, nutrition counselling is an effective measure to bring about favourable and significant changes in the diabetic state ${ }^{[6]}$. Continuous education programs and counselling should be conducted for diabetic patients to emphasize and re-emphasize the importance of risk factor, prevention, medication and behavioural changes ${ }^{[7]}$. Overall, it is the pharmacist's role to reduce the disease progression and to prevent the DM complications. Through effective patient counselling, pharmacist can establish an effective therapeutic relationship ${ }^{[8]}$.

\section{MATERIALS AND METHODS}

A randomized controlled pilot study was conducted for a period of 6 mo between December 2015 and May 2016 in the rural areas of Kumarapalayam, Tamilnadu. Institutional ethical committee approval was obtained before the conduct of study. Patients with DM-2 of both genders, aged between 21-80 y with or without co-morbidities were included in the study. Pregnant, lactating women, paediatric and psychiatric patients were excluded. Sixty patients were enrolled as subjects based on inclusion and exclusion criteria. During each visit, patients fasting blood glucose levels were measured by using a glucometer (Sugarchek, TaiDoc Technology Corporation, New Taipei City, Taiwan).

All the patients enrolled were evaluated for a socio-demographic factor, followed by employment of knowledge, attitude and practice (KAP) and WHO-BREF questionnaire. A pre-validated KAP questionnaire was employed, consisting 25 questions (knowledge-14, attitude-5 and practice-6) ${ }^{[9]}$. Each correct answer was given score of one while the wrong answer was given zero score. The WHOQOL-BREF questionnaire developed by World Health Organization (WHO), a short form of WHOQOL-100, is across-cultural instrument.Itcontains two items from the Overall QOL and general health and 24 items of satisfaction with rating on a 5-point Likert scale. The 24 items were divided into four domains: physical health with 7 items (DOM1), psychological health with 6 items (DOM2), social relationships with 3 items (DOM3) and environmental health with
8 items (DOM4). Each item of the WHOQOL-BREF was scored from 1 to 5 on a response scale.

\section{Study procedure:}

After obtaining patient consent, the demographic data (age, gender, social status, economic status, and diagnosis and drug usage) were collected using a suitable data collection form. A total of 60 patients were randomized into control $(n=30)$ and intervention $(n=30)$ group based on age. The study design was divided into baseline, $1^{\text {st }}$ visit and $2^{\text {nd }}$ visit with a difference of 1 mo between each visit. The baseline demography data, fasting blood sugar (FBS) levels, KAP and QOL scores were obtained from control and intervention group. After incorporation of baseline data, intervention group received patient counselling in local language (1) orally, (2) visually and (3) using patient information leaflets (PIL) between periods of each follow-up. The patients in the controlled group received counselling and PIL only at the end of the study. The blood sugar level, scores of KAP and QOL were obtained for both intervention (after each post counselling session) and control groups at the end of $1^{\text {st }}$ and $2^{\text {nd }}$ visit.

The data gathered was statistically analysed by SPSS, version 16, based on a paired t-test. All 'P' values $<0.05$ were considered significant. Content of counselling was designed as follows: Before $1^{\text {st }}$ follow-up: audio visuals session about general awareness of DM (causes, diagnosis, normal values of blood glucose, complications) in the first $2 \mathrm{w}$ of the first month. Audio visual session and oral counselling on lifestyle modifications, which include diet modification, weight reduction, physical exercise, cessation of risk factors (smoking and alcohol intake) and prevention of complications in the second $2 \mathrm{w}$ of the first month. Before $2^{\text {nd }}$ follow-up: drug compliance (importance of drugs, mode of administration and common side effects) in the first $2 \mathrm{w}$ of the second month. PIL about the disease, dietary plan, management of smoking, weight reduction in second $2 \mathrm{w}$ of second month.

\section{RESULTS AND DISCUSSION}

The total sample size studied was 60 , of which $24(40 \%)$ were males and $36(60 \%)$ were females (Table 1). Age-wise distribution (Table 1) shows that most of the DM patients were found to be more in the age group ranging between $41-60$ y $(61.66 \%)$ than in $61-80$ y group (31.66\%). In this study, the distribution of DM was more in primary group (35\%) than in the secondary $(33 \%)$, illiterate $(22 \%)$ and graduate $(10 \%)$ group (Table 1). 
Percent body mass index (BMI) of DM patients is shown in Table 2, where the control and the intervention groups were categorized as underweight, normal weight, overweight and obese. In addition, the number of patients with lack of physical activity was found to be identical in both the groups 22 (73.33\%, Table 2). The major co-morbidities of the study population, along with type $2 \mathrm{DM}$ was hypertension 17 (28.33\%), followed by hypertension with hyperlipidaemia $3(5 \%)$ and hypertension with gastric ulcer 2 (3.33\%, Table 3$)$. The distribution of antidiabetic drugs in study population was presented in Table 4 . The mean reduction in blood glucose levels from baseline $(166.1 \pm 66.60)$ to final follow-up $(118.27 \pm 11.70)$ in intervention group was found to be highly significant when compared to control group (Table 5).

Scores of intervention group from baseline to second follow-up (Table 6) revealed that the mean increases in physical health from $11.43 \pm 1.305$ to $14.15 \pm 1.358$ was statistically significant $(\mathrm{P} \leq 0.001)$ in comparison to the control group, where the score from baseline to

TABLE 1: DEMOGRAPHIC CHARACTERISTICS OF STUDY SUBJECTS

\begin{tabular}{lccc}
\hline Variable & $\begin{array}{c}\text { Number of } \\
\text { patients }(\mathrm{n}=60)\end{array}$ & $\begin{array}{c}\text { Control } \\
(\mathrm{n}=30)\end{array}$ & $\begin{array}{c}\text { Intervention } \\
(\mathrm{n}=30)\end{array}$ \\
\hline Male & $24(40 \%)$ & $10(33.3 \%)$ & $14(46.7 \%)$ \\
Female & $36(60 \%)$ & $20(66.7 \%)$ & $16(53.3 \%)$ \\
\multicolumn{4}{c}{ Age group (y) } \\
\hline $21-40$ & $4(6.7 \%)$ & $2(6.7 \%)$ & $2(6.7 \%)$ \\
$61-60$ & $37(61.7 \%)$ & $18(60 \%)$ & $19(63.3 \%)$ \\
& $19(31.7 \%)$ & $10(33.3 \%)$ & $9(30 \%)$ \\
Illiterate & $13(21.7 \%)$ & $6(20 \%)$ \\
Primary & $21(35 \%)$ & $14(46.7 \%)$ & $7(23.3 \%)$ \\
Secondary & $20(33.3 \%)$ & $9(30 \%)$ & $11(36.7 \%)$ \\
Graduate & $6(10 \%)$ & $1(3.3 \%)$ & $5(16.7 \%)$ \\
\hline
\end{tabular}

TABLE 2: DISTRIBUTION OF BMI IN DIABETIC PATIENTS

\begin{tabular}{|c|c|c|}
\hline \multirow{2}{*}{$\begin{array}{l}\text { Distribution of diabetic } \\
\text { patients }\end{array}$} & \multicolumn{2}{|c|}{ Number of patients $(n=60)$} \\
\hline & $\begin{array}{c}\text { Control } \\
(n=30)\end{array}$ & $\begin{array}{c}\text { Intervention } \\
(n=30)\end{array}$ \\
\hline \multicolumn{3}{|c|}{ BMI } \\
\hline Underweight $<18.5 \mathrm{~kg} / \mathrm{m}^{2}$ & $1(3.3 \%)$ & $0(0 \%)$ \\
\hline Normal weight18.6-24.9 kg/m² & $12(40 \%)$ & $13(43.3 \%)$ \\
\hline Overweight $25-29.9 \mathrm{~kg} / \mathrm{m}^{2}$ & $12(40 \%)$ & $14(46.6 \%)$ \\
\hline Obese $>30 \mathrm{~kg} / \mathrm{m}^{2}$ & $5(16 \%)$ & $3(10 \%)$ \\
\hline \multicolumn{3}{|c|}{ Physical activity } \\
\hline Exercise & $8(26.66 \%)$ & $8(26.66 \%)$ \\
\hline Lack of exercise & $22(73.33 \%)$ & $22(73.33 \%)$ \\
\hline
\end{tabular}

BMI stands for body mass index

September-October 2017
TABLE 3: DISTRIBUTION OF DIABETIC PATIENTS WITH CO-MORBIDITIES

\begin{tabular}{lcc}
\hline $\begin{array}{l}\text { Diabetic with } \\
\text { comorbidities }\end{array}$ & $\begin{array}{c}\text { Number of } \\
\text { patients }(\mathbf{n}=\mathbf{6 0})\end{array}$ & $\begin{array}{c}\text { Percentage } \\
(\%)\end{array}$ \\
\hline DM-2 & 31 & 51.66 \\
DM-2, HTN & 17 & 28.33 \\
DM-2, HLD & 1 & 1.66 \\
DM-2, HTN, HLD & 3 & 5.00 \\
DM-2, HTN, GU & 2 & 3.33 \\
DM-2, epilepsy & 1 & 1.66 \\
DM-2, HTN, epilepsy & 1 & 1.66 \\
DM-2, GU & 2 & 3.33 \\
DM-2, OA & 1 & 1.66 \\
DM-2, thyroid disease & 1 & 1.66 \\
\hline
\end{tabular}

DM 2 is type 2 diabetes mellitus, HTN is hypertension, HLD is hyperlipidaemia, GU is gastric ulcer, OA is osteoarthritis

second follow-up $(11.57 \pm 1.357$ to $11.90 \pm 1.709)$ was statistically insignificant.

Scores of intervention group from baseline to second follow-up (Table 6) showed that the mean increases in psychological health from $11.03 \pm 1.564$ to $13.63 \pm 1.402$ was clinically significant $(\mathrm{P}<0.001)$ in comparison to the control group, where the score from baseline to second follow-up $(11.37 \pm 1.351$ to $11.70 \pm 1.512)$ was statistically insignificant.

Scores of intervention group from baseline to second follow up (Table 6) showed that the mean increases in social relationship from $11.97 \pm 4.072$ to $13.43 \pm 2.300$ was clinically significant $(\mathrm{P}<0.001)$ in comparison to the control group, where the score from baseline to second follow-up $(11.23 \pm 2.515$ to $11.23 \pm 2.445)$ was statistically insignificant.

Scores of intervention group from baseline to second follow-up (Table 6) revealed that the mean increases in environmental health from $11.87 \pm 1.907$ to $14.40 \pm 1.925$ was clinically significant $(\mathrm{P}<0.001)$ in comparison to the control group, where the score from baseline to second follow-up $(11.63 \pm 1.810$ to $11.90 \pm 1.807)$ was statistically insignificant.

Scores of intervention group from baseline to second follow up (Table 7) revealed that the mean increases in knowledge from $8.17 \pm 2.245$ to $15.53 \pm 0.90$ was clinically significant $(\mathrm{P}<0.001)$ in comparison to the control group, where the score from baseline to second follow-up ( $7.63 \pm 2.297$ to $8.30 \pm 2.168)$ was statistically insignificant.

Scores of intervention group from baseline to second follow up (Table 7) showed that the mean increases in attitude from $3.13 \pm 1.106$ to $5.37 \pm 1.098$ was clinically significant $(\mathrm{P}<0.001)$ in comparison to the control 
TABLE 4: DISTRIBUTION OF ANTIDIABETIC DRUG IN CONTROL AND INTERVENTION GROUP

\begin{tabular}{|c|c|c|}
\hline Antidiabetic drug & Control $(n=30)$ & Intervention $(\mathrm{n}=30)$ \\
\hline Monotherapy & $\begin{array}{l}\text { Metformin-7 (23.3\%) } \\
\text { Insulin-1 (3.3\%) }\end{array}$ & $\begin{array}{l}\text { Metformin-2 (6.7\%) } \\
\text { Glipizide-2 (6.7\%) } \\
\text { Glimepiride-1 (3.3\%) }\end{array}$ \\
\hline Dual therapy & $\begin{array}{l}\text { Glibenclamide/metformin-8 }(26.7 \%) \\
\text { Glimepiride/metformin-5 (16.7\%) }\end{array}$ & $\begin{array}{c}\text { Glimepiride/metformin-7 (23.3\%) } \\
\text { Glimepiride/voglibose-1 (3.3\%) } \\
\text { Glibenclamide/metformin-5 (16.7\%) } \\
\text { Gliclazide/metformin-1 (3.3\%) }\end{array}$ \\
\hline Triple therapy & $\begin{array}{l}\text { Pioglitazone/glipizide/metformin-1 (3.3\%) } \\
\text { Metformin/pioglitazone/glimepiride-1 (3.3\%) } \\
\text { Glimepiride/metformin/voglibose-3 (10\%) } \\
\text { Glibenclamide/metformin/insulin-1 (3.3\%) } \\
\text { Glibenclamide/metformin/voglibose-1 (3.3\%) }\end{array}$ & $\begin{array}{c}\text { Glibenclamide/metformin/pioglitazide-2 (6.7\%) } \\
\text { Metformin/pioglitazone/glimepiride-1 (3.3\%) } \\
\text { Glimepiride/metformin/glipizide-1 (3.3\%) } \\
\text { Glimepiride/metformin/voglibose-2 (6.7\%) } \\
\text { Glimepiride/metformin/glucosamine-1 (3.3\%) } \\
\text { Gliclazide/metformin/voglibose-1 (3.3\%) }\end{array}$ \\
\hline Multi therapy & $\begin{array}{l}\text { Pioglitazone/metformin/glimepiride/ } \\
\text { voglibose-1 (3.3\%) }\end{array}$ & $\begin{array}{l}\text { Pioglitazone/metformin/glimepiride/ voglibose-1 } \\
\qquad(3.3 \%)\end{array}$ \\
\hline Not on any drug & $1(3.3 \%)$ & $2(6.7 \%)$ \\
\hline
\end{tabular}

FBS-Fasting blood sugar

TABLE 5: COMPARISON OF BLOOD SUGAR LEVELS OF DIABETIC PATIENTS IN CONTROL AND INTERVENTION GROUP

\begin{tabular}{lccc}
\hline Groups & Control $(\mathrm{n}=30)$ FBS & Intervention $(\mathrm{n}=30)$ FBS & P-value \\
\hline Baseline & $158.87 \pm 67.70$ & $166.1 \pm 66.60$ & 0.645 \\
$1^{\text {st }}$ Follow up & $160.37 \pm 49.84$ & $134.77 \pm 23.07$ & 0.010 \\
$2^{\text {nd }}$ Follow up & $167.6 \pm 43.31$ & $118.27 \pm 11.70$ & $0.000^{*}$ \\
\hline
\end{tabular}

$P$ value stands for calculated probability of findings observed. ${ }^{*} P<0.001$ significant; $S D$ is standard deviation for $n=60$

TABLE 6: QUALITY OF LIFE SCORE OF DIABETIC PATIENTS IN CONTROL AND INTERVENTION GROUP

\begin{tabular}{|c|c|c|c|c|}
\hline QOL & Control $($ mean \pm SD) & Intervention (mean $\pm \mathrm{SD})$ & $\mathrm{t}$-value & P-value \\
\hline \multicolumn{5}{|c|}{ Domain 1 (Physical health) } \\
\hline Baseline & $11.57 \pm 1.35$ & $11.43 \pm 1.30$ & 0.34 & 0.732 \\
\hline $1^{\text {st }}$ follow up & $11.70 \pm 1.44$ & $13.10 \pm 1.15$ & 3.81 & $0.001^{*}$ \\
\hline $2^{\text {nd }}$ follow up & $11.90 \pm 1.70$ & $14.15 \pm 1.35$ & 5.12 & $0.000^{*}$ \\
\hline \multicolumn{5}{|c|}{ Domain 2 (Psychological) } \\
\hline Baseline & $11.37 \pm 1.35$ & $11.03 \pm 1.56$ & 0.85 & 0.400 \\
\hline $1^{\text {st }}$ follow up & $11.63 \pm 1.29$ & $12.67 \pm 1.09$ & 3.16 & $0.004^{*}$ \\
\hline $2^{\text {nd }}$ follow up & $11.70 \pm 1.51$ & $13.63 \pm 1.40$ & 5.04 & $0.000^{*}$ \\
\hline \multicolumn{5}{|c|}{ Domain 3 (Social relationship) } \\
\hline Baseline & $11.23 \pm 2.51$ & $11.97 \pm 4.07$ & 0.82 & 0.419 \\
\hline $1^{\text {st }}$ follow-up & $11.40 \pm 2.55$ & $12.50 \pm 1.79$ & 2.06 & 0.048 \\
\hline $2^{\text {nd }}$ follow up & $11.23 \pm 2.44$ & $13.43 \pm 2.30$ & 3.65 & $0.001^{*}$ \\
\hline \multicolumn{5}{|c|}{ Domain 4 (Environment) } \\
\hline Baseline & $11.63 \pm 1.81$ & $11.87 \pm 1.90$ & 0.48 & 0.633 \\
\hline $1^{\text {st }}$ follow up & $11.77 \pm 1.79$ & $13.50 \pm 1.75$ & 3.83 & $0.001^{*}$ \\
\hline $2^{\text {nd }}$ follow up & $11.90 \pm 1.80$ & $14.40 \pm 1.92$ & 5.09 & $0.000^{*}$ \\
\hline
\end{tabular}

QOL stands for quality of life and SD is standard deviation for $n=60$. $P$ value stands for calculated probability of findings observed. ${ }^{*}<0.001$ significant; t-value is test statistic

group, where the score from baseline to second follow-up (2.77 \pm 1.251 to $2.80 \pm 1.243)$ was statistically insignificant.

The randomized controlled pilot study was focused on the impact of patient counselling and education, offered by pharmacist on patients' KAP and QOL, among diabetic patients. DM has a huge impact on QOL, which serves to measure the importance of health outcomes in chronic disorders. This study results showed how physical, psychological, social, environmental, and general health were affected in DM-2 patients. More than half of the subjects in this study were females $(60 \%)$. This study was similar to the study conducted among the adults in Indonesia ${ }^{[10]}$. The majority of the DM-2 patients in this study were in the age group between $41-60 \mathrm{y}$. About $50 \%$ of adults in the world with diabetes were between the ages of 40 and $59 \mathrm{y}$ in $2014^{[1]}$. Several studies had reported that, 
TABLE 7: KAP SCORE OF DIABETIC PATIENTS IN CONTROL AND INTERVENTION GROUP

\begin{tabular}{lcccc}
\hline KAP & Control $($ Mean \pm SD) & Intervention $($ Mean \pm SD) & t-value & p-value \\
\hline \multicolumn{5}{c}{ Knowledge } \\
Baseline & $7.63 \pm 2.29$ & $8.17 \pm 2.24$ & 1.05 & 0.301 \\
$1^{\text {st }}$ follow up & $8.17 \pm 2.26$ & $12.50 \pm 1.48$ & 8.52 & $<0.001^{*}$ \\
$2^{\text {nd }}$ follow up & $8.30 \pm 2.16$ & $15.53 \pm 0.90$ & 17.11 & $<0.001^{*}$ \\
& & Attitude/practice & & \\
\hline Baseline & $2.77 \pm 1.25$ & $3.13 \pm 1.10$ & 1.28 & 0.209 \\
$1^{\text {st }}$ follow up & $2.77 \pm 1.22$ & $4.37 \pm 1.15$ & 5.23 & $<0.001^{*}$ \\
$2^{\text {nd }}$ follow up & $2.80 \pm 1.24$ & $5.37 \pm 1.09$ & 8.29 & $<0.001^{*}$ \\
\hline
\end{tabular}

KAP stands for knowledge, attitude and practice and SD is standard deviation for $n=60$. $P$ value stands for calculated probability of findings observed. ${ }^{*} P<0.001$ significant; $t$-value is test statistic

the age groups between 41-60 y are more prone to be $\mathrm{DM}^{[6,11,12]}$. It has been reported that insulin secretion gradually reduces at a rate of nearly $0.7 \%$ per year with ageing. Ageing has no impact on insulin sensitivity independent of changes in body composition. Age-related decrease in insulin production results from changes in $\beta$-cell mass and/or function ${ }^{[13]}$.

In this study, most of the DM-2 patients were found to be having primary education. Patients were also found to have a very poor knowledge towards DM, which probably accounted for poor self-management skills by the patients ${ }^{[1]}$. Appropriate educational approach and follow-up have to be employed to promote selfmanagement behaviours and QOL of DM-2 patients ${ }^{[14]}$.

Hypertension and hyperlipidaemia were most common comorbidities observed among the subjects. Hyperlipidaemia is the most common comorbidity of DM and it predisposes them to premature atherosclerosis and macrovascular complications ${ }^{[15]}$. In insulinresistant states, reduction in endothelial cell lipoprotein lipase activity results in damage to endothelial cells. Hyperglycemia activates protein kinase $\mathrm{C}$ in endothelial cells, which increases production of vasoconstrictor prostaglandins, endothelia and angiotensin converting enzyme (ACE), and platelet and vascular growth factors, which enhance vasomotor reactivity and vascular remodelling and growth ${ }^{[16]}$. In this study, most of the DM-2 patients were found to be without any sort of physical activity. Physical activity improves the utilization of blood sugar levels in diabetic patients. Engaging in vigorous exercise, once a week, had been reported to lower incidence of self-reported type $2 \mathrm{DM}$ than women who did not exercise weekly ${ }^{[17]}$. Leisuretime physical activity and other physical activities are also associated with a reduction in risk of diabetes ${ }^{[18]}$. In the study population, $10 \%$ had not taken any drugs in addition to antidiabetic drugs.

In this study, there was a gradual reduction in FBS levels in the intervention group. Several studies have reported that patient counselling and lifestyle modification improves the patient knowledge about such diseases, QOL and also reduces the blood sugar level ${ }^{[7,19,20]}$. There was an improvement in QOL score in the intervention group. Pharmacist intervention helped in better controlling of diabetes and improved the QOL ${ }^{[11]}$.

KAP scores of the DM-2 patients were poor at the baseline due to lack of patient education about diseases, drugs and lifestyle modification. The KAP scores increased at $1^{\text {st }}$ and $2^{\text {nd }}$ follow-up. Teaching diabetic patients about their illness is imperative and vital, because the success of the DM treatment depends on lifestyle modifications along with drug therapy ${ }^{[9]}$. Lifestyle changes must incorporate careful dietary planning, use of medication, and home blood sugar monitoring techniques for all diabetic patients ${ }^{[21]}$.

The results of the study showed significant reduction in FBS levels from baseline to final follow-up through effective patient counselling. This study also revealed a significant enhancement in the QOL of patients following pharmacist-mediated counselling since there was an improvement in QOL score from baseline to final follow-up. The applied health education was an effective tool that implicated a significant change in patients' KAP towards different aspects of DM. Appropriate medication management, targeting glycaemic control, hypertension, and lipid management were important for reducing morbidity and mortality, and improving long-term QOL for patients diagnosed with DM.

\section{Acknowledgements:}

We would like to express our thanks to the Head, Department of Pharmacy Practice and our departmental staffs for their valuable suggestions and recommendations. 


\section{Conflict of interest:}

Nil.

\section{Financial support and sponsorship:}

Nil.

\section{REFERENCES}

1. https://www.idf.org/e-library/epidemiology-research/ diabetes-atlas/19-atlas-6th-edition.html.

2. Ramanath K, Santhosh YL. Impact of clinical pharmacist provided patient education on QOL outcome in type 2 diabetes mellitus in rural population. Asian J Pharm Clin Res 2011;4:15-20.

3. WHOQOL Group. The WHO quality of life assessment (WHOQOL): development and general psychometric properties. Soc Sci Med 1998;46:1569-85.

4. Skevington SM, Lofty M, O'Connell KA. The World Health Organization's WHOQOL-BREF quality of life assessment: psychometric properties and results of the international field trial. Qual Life Res 2004;13:299-310.

5. Ramesh A, Madhu S. Influence of post discharge counselling on health outcomes in diabetic and hypertensive patients. Asian J Pharm Clin Res 2011;4:28-33.

6. Renu M, Aman A. Impact of nutrition counselling on blood glucose level of patients suffering from non-insulin dependent diabetes mellitus. Ethno Med 2010;4:203-5.

7. Khan NA, Saxena S, Handa S, Habib A, Abid M, Patra A, et al. Impact of counseling on diabetic patients. Int J Pharm Clin Res 2010;2:72-5.

8. Lewis RK, Lasack NL, Lambart BL, Connor SE. Patient counselling- a focus on maintaining the therapy. Am J Health Syst Pharm 1997;54;2084-98.

9. Subish P, Leelavathi D, Padma G, Nidin M, Nibu P. Knowledge, attitude, and practice outcomes: evaluating the impact of counselling in hospitalized diabetic patients in India. Pharm Therapeut 2006;31:383-96.

10. Aklima S, Charuwan K, Ploenpit T. Dietary Behaviours among patients with type 2 diabetes mellitus in Indonesia. Nurse Media J Nursing 2013;3:499-509.

11. Shivasharanappa JA, Biradar SS, Srinivas R, Raghu YR, Ravi PD. Assessment of pharmacist mediated patient counselling on quality of life in type- 2 diabetes patients at a tertiary care hospital. Indo Am J Pharm Res 2014;4:3468-76.

12. $\mathrm{Ng} \mathrm{SH,} \mathrm{Chan} \mathrm{KH}$, Lian ZY, Chuah YH, Waseem AN, Kadirvelu A. Reality vs Illusion: Knowledge, attitude and practice among diabetic patients. Int J Collab Res Intern Med Public Health 2012;4:723-32.

13. Ervin S, Muhammad Z, Susan M, Hans J, Timon W, Christian $\mathrm{M}$, et al. Effect of aging on glucose homeostasis. Diabetes Care 2008;31:539-43.

14. Nazl A, Kenan K, Tanju G. The impact of patient education on diabetes empowerment scale (DES) and diabetes attitude scale (DAS-3) in patients with type 2 diabetes. Turk J Med Sci 2008;38:49-57.

15. Khursheed M, Bikha R, Syed Z. Lipid profile of patients with diabetes mellitus (A multidisciplinary study). Lancet 2011;12:1382-4.

16. Sowers JR, Epstein M. Diabetes mellitus and associated hypertension, vascular disease, and nephropathy. J Hypertens 1995;26:869-87.

17. Manson JE, Rimm EB, Stampfer MJ, Colditz GA, Willett WC, Krolewski AS, et al. Physical activity and incidence of non-insulin dependent diabetes mellitus in women. Lancet 1991;338:774-8.

18. Rashid MA. Clinical study-effect of physical activity and obesity on type 2 diabetes in a middle-aged population. $\mathrm{J}$ Environ Public Health 2009;2009:1-5.

19. Arun KP, Murugan R, Kanna MR, Rajalakshmi S, Kalaiselvi $\mathrm{R}$, Komathi V. The impact of pharmaceutical care on the clinical outcome of diabetes mellitus among a rural patient population. Int J Diabetes Dev Ctries 2008;28:15-8.

20. Adepu R, Rasheed A, Nagavi BG. Effect of patient counseling on quality of life in type 2 diabetes mellitus patients in two selected South Indian community pharmacies: a study. Indian J Pharm Sci 2007;69: 519-24.

21. Ana S, Radmila V. Quality of life in type 2 diabetic patients. Sci J Facul Med Nis 2014;31:193-200. 